

\title{
Ecophysiological dynamic model of individual growth of Ruditapes philippinarum
}

Jonathan Flye-Sainte-Marie, Fred Jean, Christine Paillard, Susan Ford, Eric

Powell, Eileen E. Hofmann, John Klinck

\section{To cite this version:}

Jonathan Flye-Sainte-Marie, Fred Jean, Christine Paillard, Susan Ford, Eric Powell, et al.. Ecophysiological dynamic model of individual growth of Ruditapes philippinarum. Aquaculture, 2007, 266 (1-4), pp.130-143. 10.1016/j.aquaculture.2007.02.017 . hal-00452257

\section{HAL Id: hal-00452257 \\ https://hal.univ-brest.fr/hal-00452257}

Submitted on 2 Feb 2010

HAL is a multi-disciplinary open access archive for the deposit and dissemination of scientific research documents, whether they are published or not. The documents may come from teaching and research institutions in France or abroad, or from public or private research centers.
L'archive ouverte pluridisciplinaire HAL, est destinée au dépôt et à la diffusion de documents scientifiques de niveau recherche, publiés ou non, émanant des établissements d'enseignement et de recherche français ou étrangers, des laboratoires publics ou privés. 


\title{
Ecophysiological dynamic model of individual growth of Ruditapes philippinarum *
}

\author{
Jonathan Flye Sainte Marie ${ }^{a}$, Fred Jean ${ }^{a}, *$, Christine Paillard ${ }^{a}$, \\ Susan Ford ${ }^{\mathrm{b}}$, Eric Powell ${ }^{\mathrm{b}}$, Eileen Hofmann ${ }^{\mathrm{c}}$, John Klinck ${ }^{\mathrm{c}}$ \\ a IUEM - LEMAR, Place Copernic, 29280 Plouzané, France \\ ${ }^{\mathrm{b}}$ Haskin Shellfish Research Laboratory, Rutgers University, 6959 Miller Avenue, \\ Port Norris, NJ 08349 USA \\ ${ }^{\mathrm{c}}$ Center for Coastal Physical Oceanography, Old Dominion University, Crittendon \\ Hall, Norfolk, VA 23529, USA
}

\begin{abstract}
A bioenergetics model of the Manila clam (Ruditapes philippinarum) was built to simulate growth, reproduction and spawning in culture and fishery field sites in Marennes-Oléron Bay (French Atlantic coast). The model is driven by two environmental variables: temperature and food supply. The food supply and the clam's filtration rate determine soft tissue condition index, which in turn drives clam growth and reproduction. The model was calibrated and then validated using two independent data sets.

This paper discusses the difficulty of comparing experimental data and individual model outputs when asynchronous spawning events occur in the studied population. In spite of this difficulty, the simulations reproduce the typical pattern of growth and reproduction of the Manila clam.

Simulations showed that water column chlorophyll $a$ concentration is not a perfect estimator of food resources for a near bottom suspension feeder such as the Manila clam and emphasize the lack of knowledge about Ruditapes philippinarum nutrition.

The individual growth model presented in this paper will be integrated into a numerical population model describing the host-parasite-environment relationship in Brown Ring Disease, caused by the bacterium Vibrio tapetis.
\end{abstract}

Key words: model, individual growth, energy balance, reproduction, food input, Brown Ring Disease

\footnotetext{
* Supported by NSF-CNRS joint program

* Coresponding author.
} 


\section{Introduction}

The Manila clam (Ruditapes philippinarum) was introduced for aquaculture purposes to France between 1972 and 1975 (Flassch and Leborgne, 1992). In France, this venerid culture became increasingly widespread, and since 1988 natural populations have colonized most embayments along the French Atlantic coast, resulting in a fishery of ca 1500 tons in the Gulf of Morbihan at the end of the 1990s. R. philippinarum is often affected by high mortalities in late winter, which considerably limit aquaculture and fisheries production. These mortalities were first associated with unfavourable environmental factors such as low trophic resources, cold temperatures and low salinity (Goulletquer, 1989b; Bower, 1992). Later, they were attributed to Brown Ring Disease (BRD), a bacterial disease induced by the pathogen Vibrio tapetis (Paillard et al., 1989; Paillard and Maes, 1990), in conjunction with low condition index and low biochemical reserves (Goulletquer, 1989a). BRD progression in clams and $V$. tapetis strategies for infection have been described in depth by Paillard et al. (1994) and Paillard and Maes (1994). Infections may theoretically occur any time of the year, but BRD development may be modulated by environmental conditions (Paillard et al., 2004) and clam's defence system (Allam and Paillard, 1998; Allam et al., 2000). In addition these authors showed that BRD development is modulated by the energy balance of the clam.

As a first step in developing a numerical model describing the host-pathogenenvironment relationships in $\mathrm{BRD}$, this study presents the individual ecophysiological model of growth and reproduction of the Manila clam. The aim is to describe the variability in energy balance for an individual without BRD as a function of the two main environmental factors presumed to control BRD development : the trophic resources (Goulletquer, 1989a) and the temperature (Paillard et al., 2004).

\section{Materials and methods}

\subsection{Basic concept and state variables}

The model is based on a the widely applied (see review in Bayne, 1998) scope for growth $(S F G)$ concept. The $S F G$ concept assumes that energy or matter gained by food acquisition is equal to the energy or matter lost for maintenance, growth and reproduction. SFG can be calculated as follows according to Lucas and Beninger (1985): 


$$
S F G=G g+S g+S h=C o n s-(P p+F p+R e s p+U)
$$

where: $G g$ is gonadal growth; $S g$ is somatic growth; $S h$ is shell growth; Cons is consumption (retained organic matter); $P p$ is pseudofaeces production; $F p$ is faeces production; Resp is respiration and $U$ is urea and amino acid excretion.

If $S F G<0$, energy or matter is mobilized, firstly from gonad, then from somatic tissue, and the clam loses weight while using energy reserves. If $S F G>0$, energy or matter gained is partitioned into shell, soma, and gonad. Partitioning among those three compartments is controlled both by environmental parameters (quantity and quality of food, temperature, salinity, ...) and by endogenous factors such as genotype, size and physiological condition (see e.g. Shafee and Lucas, 1982; Lucas, 1993; Goulletquer, 1989a; Pérez Camacho et al., 2003).

The conceptual design is described in Fig. 1. The structure and formulation of this model is based on the Hofmann et al. (2006) Mercenaria mercenaria growth model. The two state variables are the shell length and the total flesh weight including somatic weight and gonadal weight.

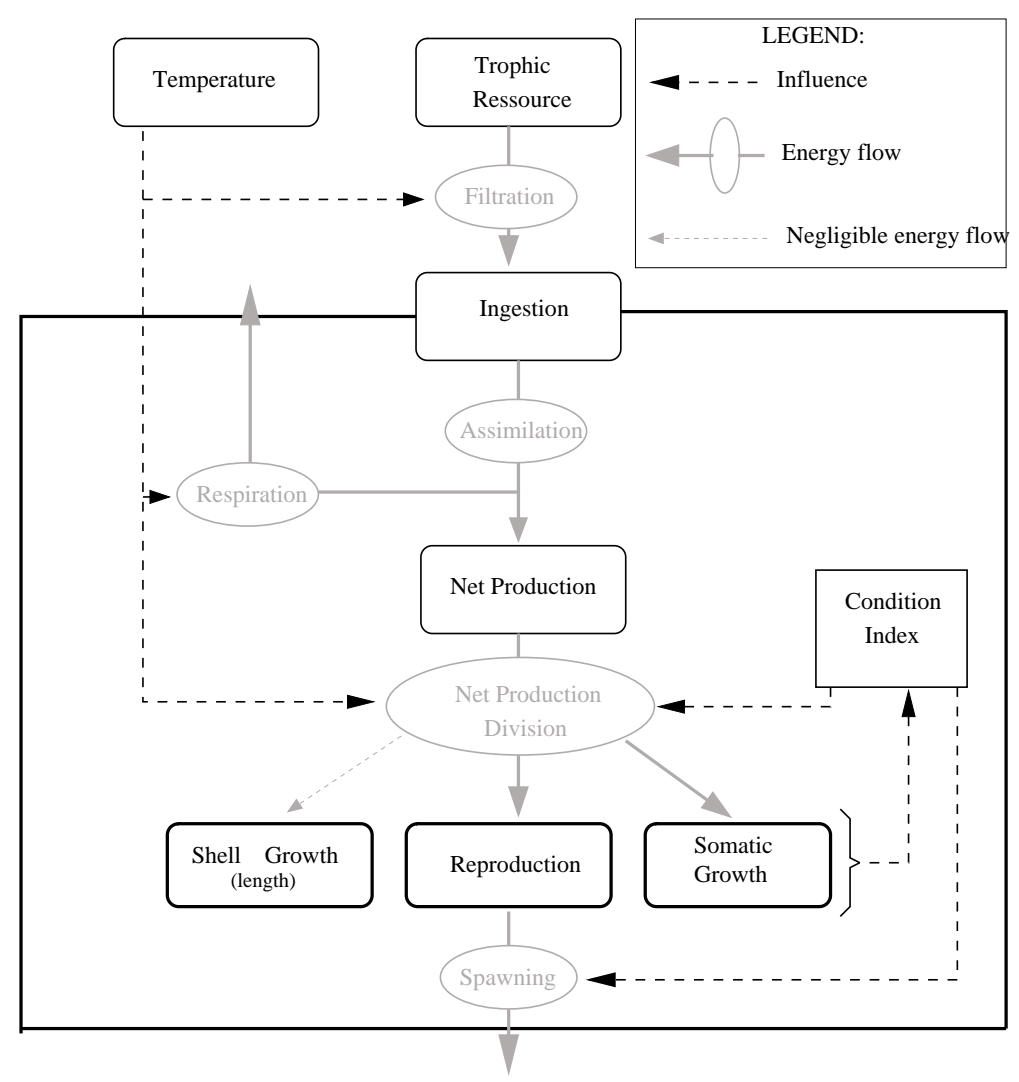

Fig. 1. Schematic of the conceptual clam growth model 


\subsection{Environmental factors}

Three data sets (Fig. 2) were extracted from Goulletquer (1989a), a survey of Manila clam aquaculture in the Marennes-Oléron basin (French Atlantic coast, see Fig. 3):

(1) a time series from Nole station (March 1984 to September 1985) of chlorophyll a $(C h l a)$ concentration was used for calibration. Temperature $(T$; ${ }^{\circ} \mathrm{C}$ ) was obtained from the same study site during a 1986 survey;

(2) two time series, one from Nole station and the other from Lilleau station, both extending from March 1985 to May 1986, were used for model validation. Both consisted of Chla concentration and temperature series.

Data from all time series were linearly interpolated to obtain daily values when necessary.

In order to evaluate trophic resources, Chla concentration was converted to ingestible dry organic matter (trophic resource Food, $g L^{-1}$ ) to take into account the pseudofaeces production step, following the equation:

$$
\text { Food }=\text { Chla } \times \text { FoodCoeff }
$$

where FoodCoeff in $g D W \mu g^{-1}$ Chla is the coefficient that converts Chla to ingestible dry organic matter.

\subsection{Physiological mechanisms formulations}

\subsubsection{Net Production}

Net production of dry organic matter (Pnet; $g$ day ${ }^{-1}$ ) was calculated with the following equation, which reflects energy gain from assimilation and loss due to respiration:

$$
\text { Pnet }=\text { Ingest } \times \text { Assim }- \text { Resp }
$$

Food acquisition Using data from literature (Goulletquer et al., 1989; Goulletquer, 1989a), the filtration rate of a 1-g $D W$ individual was estimated as a function of temperature using the following empirical equation:

$$
\operatorname{Filt}_{T}(T)=-5.6210^{-3} \times T^{2}+0.18 \times T-0.30
$$



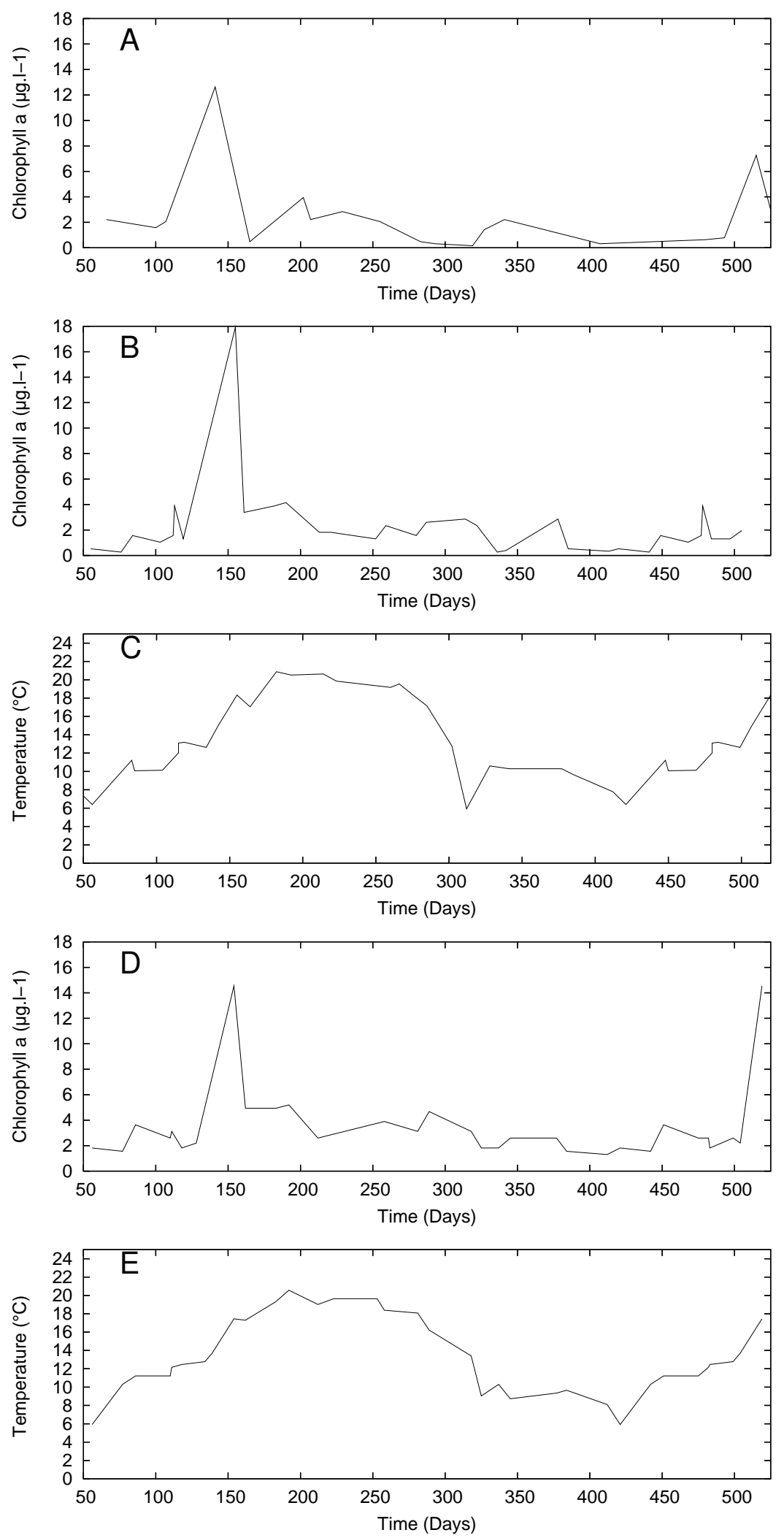

Fig. 2. Environmental data sets used for calibration and validation, interpolated from Goulletquer (1989a). Data sets A and B and C were used for the calibration at Nole station. Data sets B and C were used for validation at Nole and data sets $\mathrm{D}$ and $\mathrm{E}$ were used for validation at Lilleau station. 


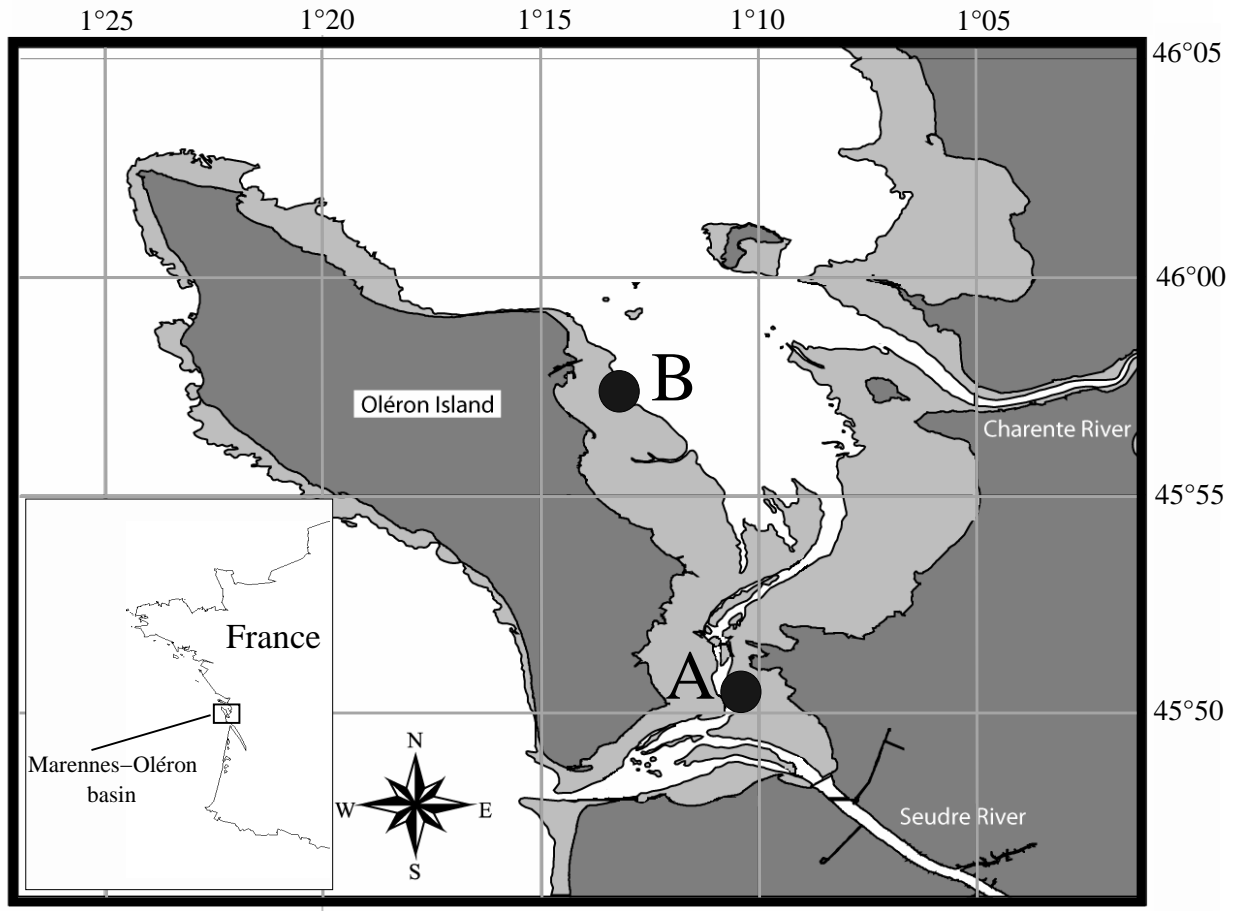

Fig. 3. Location of the the two stations studied by Goulletquer (1989a) in Marennes-Oléron basin (Atlantic coast, France). Nole (A), an estuarine station and Lilleau (B), an oceanic station.

Filt $_{T}$ in $L h^{-1}$ reaches its maximum $\left(\right.$ Filt $\left._{T}(16)=1.16 \mathrm{~L} \mathrm{~h}^{-1}\right)$ at $16{ }^{\circ} \mathrm{C}$.

Filtration rate was estimated as a function of dry weight $\left(F i l t_{W}(W)\right.$ in $m L$ min $\left.^{-1}\right)$ following the empirical equation:

$$
\operatorname{Filt}_{W}(W)=a_{f} \times W^{b f}
$$

with $a_{f}=20.049$ and $b f=0.257$.

Using equations (2) and (3), filtration rate was finally expressed as a function of individual weight and temperature (Filt; $L$ day $\left.{ }^{-1}\right)$ following the equation:

$$
\operatorname{Filt}(W, T)=\left(a_{f} \times W^{b f} \times \frac{\text { Filt }_{T}(T)}{\text { Filt }_{T}(16)}\right) \times 1.44
$$

with $a_{f}=20.049$ and $b f=0.257$ being two adjusted allometric parameters. 
Ingestion (Ingest; $g$ day ${ }^{-1}$ ) of dry organic matter can be then calculated according to the equation:

$$
\text { Ingest }=\text { Food } \times \text { Filt }
$$

Assimilation Amino acid and urea excretion is very low compared to other parameters and was thus omitted from the model. Therefore, assimilation was considered equal to absorption. Assimilation rate $(A E)$ was estimated as a function of weight according to a Michaelis-Menten formulation:

$$
A E=A E_{0}+\frac{A E_{1} \times W}{K_{A}+W}
$$

where $A E_{0}=0.1$ and $A E_{1}=0.6$ are the minimum and maximum additive assimilation rates respectively, and $K_{A}=2.74 \mathrm{~g}$ is the half-saturation constant. Assimilation (Assim; $g d a y^{-1}$ ) was then calculated following :

$$
\text { Assim }=\text { AE } \times \text { Food } \times \text { Filt }
$$

Respiration Respiration was also calculated, using data from Goulletquer et al. (1989) and Goulletquer (1989a), as a function of temperature for a 1$g D W$ individual as

$$
\operatorname{Resp}_{T}(T)=-4.7510^{-4} \times T^{2}+2.0210^{-2} \times T+2.4310^{-2}
$$

$\operatorname{Resp}_{T}\left(m l \mathrm{O}_{2} \mathrm{~h}^{-1}\right)$ reaches its maximum $\operatorname{Resp}_{T}(21)=0.24 \mathrm{ml} \mathrm{O}_{2} \mathrm{~h}^{-1}$ at $21{ }^{\circ} \mathrm{C}$. Respiration for individual clams was estimated from weight $\left(\operatorname{Resp}_{W}\right.$ in Cal $d a y^{-1}$ ) following the empirical equation:

$$
\operatorname{Resp}_{W}(W)=a_{r} \times W^{b r}
$$

where $a_{r}=27.88$ and $b r=0.85$.

Using equations (8) and (9), respiration (Resp; $g$ DW day ${ }^{-1}$ ) was finally expressed as a function of weight and temperature following the equation:

$$
\operatorname{Resp}(W, T)=\left(a_{r} \times W^{b r} \times \operatorname{Resp}_{T}(T) / \operatorname{Resp}_{T}(21)\right) \times 2.17710^{-3}
$$


with $2.17710^{-3}$ being the coefficient to convert calories to $g D W$.

\subsubsection{Condition index}

In bivalve studies, condition index is usually the ratio between shell and dry flesh weights (see review in Lucas and Beninger, 1985). In our model a condition index, based on variation of total flesh weight inside internal shell volume, like that used in oyster studies (Lawrence and Scott, 1982), was calculated as follows:

$$
C=\frac{W-W_{o}}{W_{\max }-W_{o}}
$$

where the relationship between the mean flesh weight $\left(W_{o}\right)$ and the shell length $(L)$ is

$$
W_{o}=a_{o} \times L^{b o}
$$

and $a_{o}=8.5210^{-7}$ and $b o=3.728$. The values were $a_{o}$ and $b o$ were evaluated using a composite data set (Paillard et al., unpublished data; $n=921, r^{2}=$ $0.904)$,

and

$$
W_{\max }=a_{o m} \times L^{b o}
$$

where $a_{o m}=1.7010^{-6}$.

$C$ is related to the shell weight-based condition index $(C I)$ using a linear relationship: $C=0.0124 \times C I-1.0562\left(n=558, r^{2}=0.95\right)$.

\subsubsection{Length growth}

The organic matrix is only 2 to $3 \%$ of shell weight of the Manila clam (Goulletquer and Wolowicz, 1989) and generally accounts for only a small fraction of SFG in bivalves (Thompson, 1984; Dame, 1996; Pouvreau et al., 2000); in the present model, energy allocation to shell growth was thus omitted. Therefore, shell length growth rate LgrowthRate $\left(d_{a y}{ }^{-1}\right)$ is a Michaelis-Menten function of condition index $(C)$ and is saturated as a function of the maximum length $(L)$ : 


$$
\operatorname{LgrowthRate}(L, C)=d l_{o} \times \frac{L_{\max }-L}{L_{\max }} \times \frac{C-C_{S}}{K_{l}+C-C_{S}}
$$

where $d l_{o}$ is maximum daily growth rate, $L$ is the individual length, $L_{\max }$ is the maximum clam length, $K_{l}$ is the half saturation constant and $C_{S}$ is the minimum value of $C$ for LgrowthRate $>0$. Parameters of the MichaelisMenten equation were evaluated using a composite data set from (Goulletquer, 1989a) in Marennes-Oléron Bay.

\subsubsection{Resources allocation to reproduction}

As in most venerids, the gonad of $R$. philippinarum is a diffuse organ in the visceral mass. This is the main reason why rules specifying the priorities for resource partioning by the Manila clam have not been extensively studied (Laruelle, 1999; Laruelle et al., 1994; Calvez, 2003). However, available information was used to make assumptions concerning energy allocation. Most of the information is based on various condition index and histological studies, as well as recent investigations using enzyme-linked immunosorbent assays (ELISA) to quantify egg weight (Park and Choi, 2004; Ngo and Choi, 2004). The gonad is almost never developed in clams less than $20 \mathrm{~mm}$, which is assumed to be the minimum size for reproduction (Laruelle, 1999, Calvez comm. pers). $R$. philippinarum is known to have a reproductive period extending from MarchApril to October on western European and Korean coasts. This corresponds to a period when water temperature rises above $12^{\circ} \mathrm{C}$, which is considered as the minimum temperature allowing gametogenesis (Laruelle et al., 1994; Mann, 1979; Park and Choi, 2004; Ngo and Choi, 2004). Condition index and histological studies showed that most of net production is allocated to reproduction from mid-June to the end of October (Laruelle, 1999; Calvez, 2003). This phenomenon is observed at all stations monitored by those authors along the French Atlantic coast and occurs when condition index is above a threshold value.

Reproductive effort RepEff is the adimensional fraction of net production allocated to gonadal tissues. RepEff becomes positive, and gametogenesis possible, when clam length is above a minimum (LengthRepMin $=20 \mathrm{~mm}$; Laruelle, 1999) and temperature is above a minimum (TempRepMin $=12{ }^{\circ} \mathrm{C}$; Laruelle, 1999; Park and Choi, 2004; Ngo and Choi, 2004; Mann, 1979). Below those thresholds, $\operatorname{Rep} E f f=0$. Above the thresholds, reproduction effort is calculated as a function of temperature according to

$$
\operatorname{RepE} f f=\operatorname{RepE} f f_{\text {Max }} \times \frac{1}{2} \times\left(1+\tanh \left(\frac{T-13.8}{14}\right)\right)
$$


with $\operatorname{RepEf} f_{\text {Max }}$, the maximum fraction of net production allocated to the gonad.

\subsubsection{Gamete release}

Factors triggering spawning are also not well known or intensively studied in $R$. philippinarum, for the same reasons mentioned for resource allocation. Spawns occur from May to October (Laruelle, 1999; Goulletquer, 1989a; Meneghetti et al., 2004). Spawnings and rapid rematuration after spawning are observed during the whole breeding period. Individuals are well synchronized during the first spring maturation of gametes, which is correlated to temperature increase, but this synchrony may be lost during subsequent spawnings (Laruelle et al., 1994; Toba et al., 1993; Meneghetti et al., 2004). Asynchronous partial spawnings occur from end of May until the end of August. During these partial spawnings events, only a fraction of the gonad content, corresponding to the mature ovocytes, is released. The main spawning is observed in late August or September, when almost all individuals release their entire gonadal content. Under good environmental conditions, late spawning events can occur until end of October (Goulletquer, 1989a; Laruelle, 1999; Calvez, 2003). In the model, partial and major spawning events are distinguished according to the following criteria:

- a clam is ready for a partial spawning event if its condition index and gonado-somatic index (gonad to flesh weight ratio, GSI) reach threshold values (ParIC and ParGSI, respectively). After the partial spawning event, the condition index drops to a value (ParPostIC) corresponding to the weight lost by gamete release.

- a clam is ready for a major spawning event if its GSI is above the threshold value (SpawnRatio) and it has experienced a minimal number of days of gametogenesis, which is evaluated as 119 days from the day the temperature definitively rises above $12^{\circ} \mathrm{C}$.

Threshold values for spawning events were estimated using data sets from Calvez (2003) for the Gulf of Morbihan.

\subsection{Parameter evaluation and model adjustment to experimental data}

Most of the parameters of the model were first estimated from published values for individuals without BRD symptoms ( Table 1), however, some of the parameters could not be evaluated this way and were evaluated by adjusting the model to experimental data (calibration data set at Nole). 


\subsection{Validation}

Once parameters were evaluated, the model was then validated using one data set from Nole station and one from the Lilleau station. Chlorophyll $a$ and temperature time series are shown in Fig. 2. Both data sets are from Goulletquer (1989a) (see section 2.2).

For both calibration and validation, the fit between experimental and modeled results was ascertained using a linear regression through the origin for each state variable (length, weight and condition index). The slope of regression line of modeled vs experimental values was compared to 1 ( $t$-test) and the coefficient of determination was calculated.

\section{Results}

\subsection{Model evaluation}

Results of a simulation after adjustment of the model to experimental field data are shown in Fig. 4. This simulation was obtained using the parameter values in Table 1. For all state variables, the slopes of the regression lines between observed and simulated values were not significantly different from 1 $(t$-test, $p$-value $>0.05)$.

The simulated length trajectory of a standard individual followed that of the average length observed in the field (Fig. 4A). Length growth was almost completely explained by the model $\left(r^{2}=0.98\right)$. Simulated dry weight (Fig. 4B) and condition index (Fig. 4C) were also close to field observations, even though coefficients of determination were lower $\left(r^{2}=0.77\right.$ and $r^{2}=0.66$, respectively). These lower values can be attributed to the simulated spawning pattern: the model simulated partial spawning events at days 140 and 153 (end of May and begining of June respectively). Spawning at this time was not noted by Goulletquer (1989a), who collected the data set used to calibrate and validate the model, but they are in accordance with observed spawning patterns on the French Atlantic coast (Laruelle, 1999; Calvez, 2003). A major spawning was simulated at day 230 (late August) at the date where this gamete release was observed in the field by Goulletquer (1989a). 
Table 1: Optimum values of the parameters of the model. Condition index values are expresed in the model condition index $(C)$ experimental equivalent values $(C I)$ are shown in parenthesis.

\begin{tabular}{|c|c|c|c|c|}
\hline Parameter & Explanation & Value & Unit & Evaluated from \\
\hline Filt $_{T}(16)$ & Maximum of the $F T(T)$ function (at $16^{\circ} \mathrm{C}$ ) & 1.16 & $L h^{-1}$ & Goulletquer et al. (1989); Goulletquer (1989a) \\
\hline$a_{f}$ & Allometric coeff. of the eq. relating filtration rate to DW & 20.049 & no unit & Goulletquer et al. (1989); Goulletquer (1989a) \\
\hline$b f$ & Allometric exponent of the eq. relating filtration rate to DW & 0.257 & no unit & Goulletquer et al. (1989); Goulletquer (1989a) \\
\hline$A E_{0}$ & Minimum additive assimilation rate & 0.1 & no unit & Goulletquer et al. (1989) \\
\hline$A E_{1}$ & Maximum additive assimilation rate & 0.6 & no unit & Goulletquer et al. (1989) \\
\hline$K_{A}$ & Half-sat. const. of the M.-M. eq. relating assim. rate to DW & 2.74 & $g$ & this study \\
\hline $\operatorname{Resp}_{T}(21)$ & Maximum of the $R T(T)$ function (at $21^{\circ} \mathrm{C}$ ) & 0.24 & $m l O_{2} h^{-1}$ & Goulletquer et al. (1989); Goulletquer (1989a) \\
\hline$a_{r}$ & Allometric coeff. of the eq. relating respiration rate to DW & 27.88 & no unit & Powell and Stanton (1985) \\
\hline$b r$ & Allometric exponent of the eq. relating respiration rate to DW & 0.85 & no unit & Powell and Stanton (1985) \\
\hline$a_{o}$ & Allometric coeff. of the eq. relating average DW $\left(W_{0}\right)$ to length & $851.8810^{-9}$ & no unit & Paillard (unpublished data) \\
\hline bo & Allometric exponent of the eq. relating average DW $\left(W_{0}\right)$ to length & 3.728 & no unit & Paillard (unpublished data) \\
\hline$a_{o m}$ & Allometric coeff. of the eq. relating max. DW $\left(W_{\max }\right)$ to length & $1703.7610^{-9}$ & no unit & Paillard (unpublished data) \\
\hline$L_{\max }$ & Maximum clam length & 60 & $m m$ & Mortensen and Strand (2000) \\
\hline$d l_{o}$ & Maximum length growth rate & 0.0045 & $d a y^{-1}$ & Goulletquer (1989a) \\
\hline$K_{l}$ & Half-sat. const. of the M.-M. eq. relating $C$ to length growth rate & 0.123 & no unit & Goulletquer (1989a) \\
\hline$C_{S}$ & Minimum value of $C$ for $R_{L, C}>0$ & $-0.45(49)$ & no unit & Goulletquer (1989a) \\
\hline LengthRepMin & Minimum clam length for reproduction & 20 & $\mathrm{~mm}$ & Laruelle (1999), Calvez (unpublished data) \\
\hline TempRepMin & Minimum temperature for reproduction & 12 & ${ }^{\circ} \mathrm{C}$ & Laruelle (1999) \\
\hline ParGSI & GSI threshold value for partial spawning & 0.30 & no unit & this study \\
\hline ParIC & Condition index threshold value for partial spawning & $0.50(125)$ & no unit & Calvez (2003) \\
\hline ParPostIC & condition index value after a partial spawning event & $0.23(104)$ & no unit & Calvez (2003) \\
\hline SpawnRatio & GSI threshold value for principal spawning & 0.42 & no unit & Park and Choi (2004) \\
\hline$C 2 F$ & Chla to dry ingestible org. mat. conversion coeff. at Nole station & 0.2552 & $g D W \mu g^{-1}$ & this study \\
\hline $\mathrm{C} 2 \mathrm{~F}$ & Chla to dry ingestible org. mat. conversion coeff. at Lilleau station & 0.3432 & $g D W \mu g^{-1}$ & this study \\
\hline
\end{tabular}




\subsection{Model validation}

Nole

Validation simulations at Nole station are shown in Fig. 5. For length and weight, the slopes of the regression lines between observed and simulated values were not significantly different from 1 ( $t$-test, $p$-value $>0.05)$. The simulated length trajectory (Fig. 5A) was close to observed data and the coefficient of determination was very high $\left(r^{2}=0.95\right)$. Simulated trajectories for weight (Fig. 5B) and condition index (Fig. 5C) were also near the observed data; two partial spawnings were simulated at days 154 and 187. Laruelle (1999) and Calvez (2003) showed that partial spawnings induced asynchrony of gonadal state, resulting in increased variability of flesh weight within a cohort. The two large standard deviations for weight in the field data between days 154 and day 187 tend to confirm the occurrence of such spawnings.

During the whole gamete release period, from day 150 (late May) to day 240 (begining of September), the simulated trajectory diverged from observed data because of spawnings. The importance of the principal spawning in the fall induced a divergence of the model compared to observed data. These divergences induced lower coefficients of determination between simulation and field data for weight $\left(r^{2}=0.63\right)$ and condition index $\left(r^{2}=0.78\right)$. For condition index, slope of the regression line between experimental and modeled data was 0.84 and significantly different from 1 ( $t$-test, $p$-value $<0.05)$. Nevertheless, for both weight and length, simulations were within the observed standard deviation range.

\section{Lilleau}

Validation simulations for the Lilleau site are shown in Fig. 6. For all state variables, the slopes of the regression lines between observed and simulated values were not significantly different from 1 ( $t$-test, $p$-value $>0.05)$. The simulated length trajectory followed closely the observed values at Lilleau $\left(r^{2}=0.89\right)$ and lay within standard deviation range (Fig. 6 A). Condition index was well explained by the model $\left(r^{2}=0.72\right)$ and the weight simulation was better explained than in the Nole validation simulation $\left(r^{2}=0.77\right)$. Like the Nole simulation, the first gamete emissions were simulated at the end of the spring (day 144, late May) and continued during the summer. The simulated principal spawning occured at day 227 (mid August), which was consistent with the observation of Laruelle (1999) and Calvez (2003) for the coast of Brittany, France. In early summer, many (8) partial spawnings are simulated which are not described in the field dataset of Goulletquer (1989a), thus resulting in underestimates of both weight and length growth. Dates of these 



Fig. 4. Results of the adjustment of the model to experimental data of Goulletquer (1989a) for (A) length (mm); (B) weight ( $\mathrm{g}$ DW) and (C) condition index. Continuous lines: model output. Crosses $(+)$ : observed data points. The arrow indicates the date where spawning was observed by Goulletquer (1989a). Time (days) is counted from the 1st of January 1984.

partial spawnings are in accordance with Laruelle (1999) and Calvez (2003) observations. A simulated late spawning event occured at day 285 (mid October). This gamete release event was noted in the field data set of Goulletquer (1989a) who emphasized that at Lilleau station the reproduction effort was higher than at Nole, which is consistent with the model simulation. 

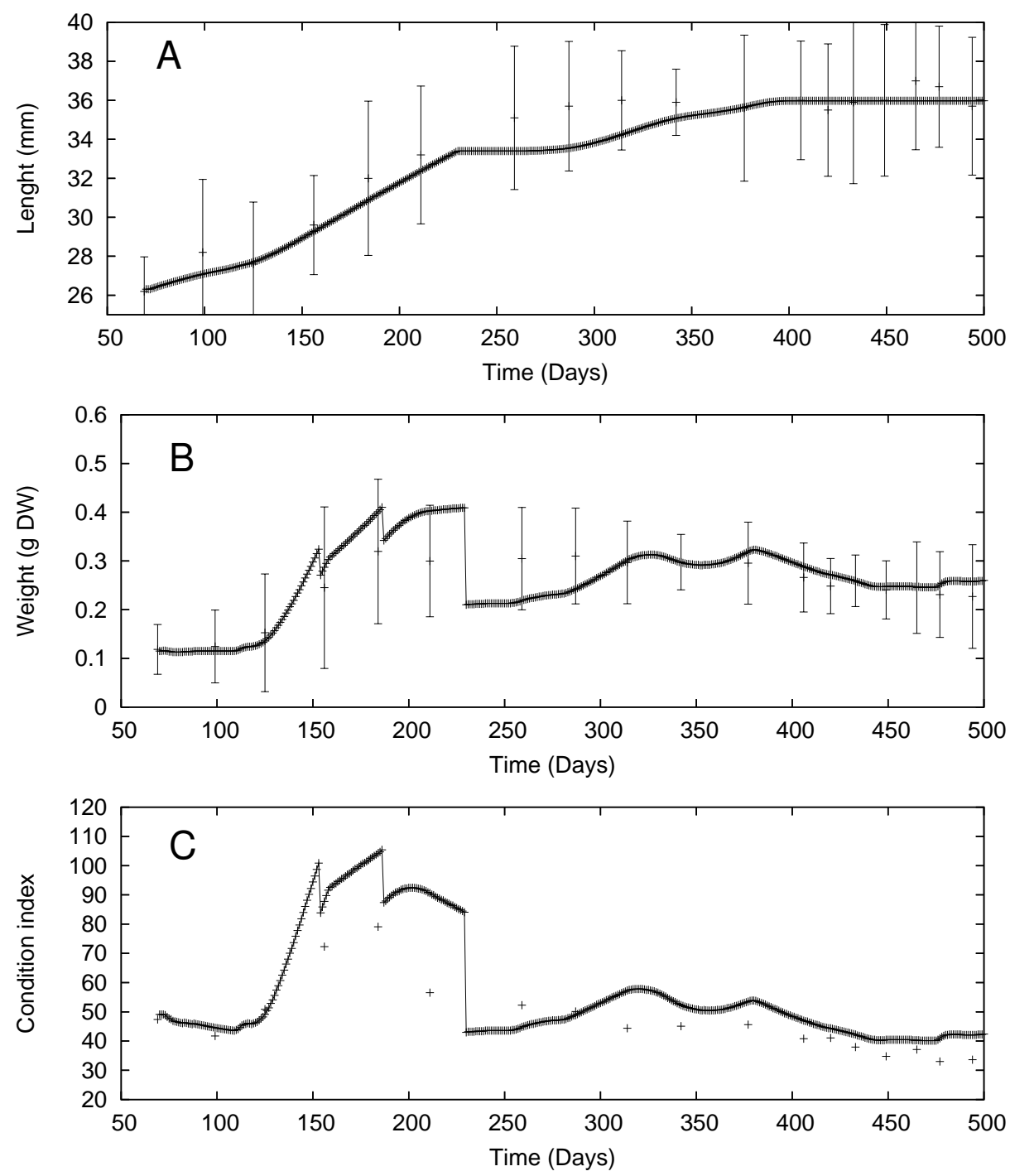

Fig. 5. Results of the validation of the model using temperature and Chla times series at the Nole Sation for length (A), weight (B) and condition index (C). Continuous lines: model output; crosses $(+)$ : observed data points; errorbars indicate standard deviation for field data (Goulletquer, 1989a). Standard deviations for condition index were not available. Time (days) is counted from the 1st of January 1985.

\section{Discussion}

\section{Shell growth}

An important and original aspect of this model, which is derived from the Hofmann et al. (2006) hard clam growth model, compared to other individual growth models based on the Scope For Growth concept (e.g. Barillé et al., 1997; Grant and Bacher, 1998; Pouvreau et al., 2000; Hawkins et al., 2002; Gangnery et al., 2003; Fréchette et al., 2005), is that condition index drives both net production division and length growth. In most scope for growth models of 

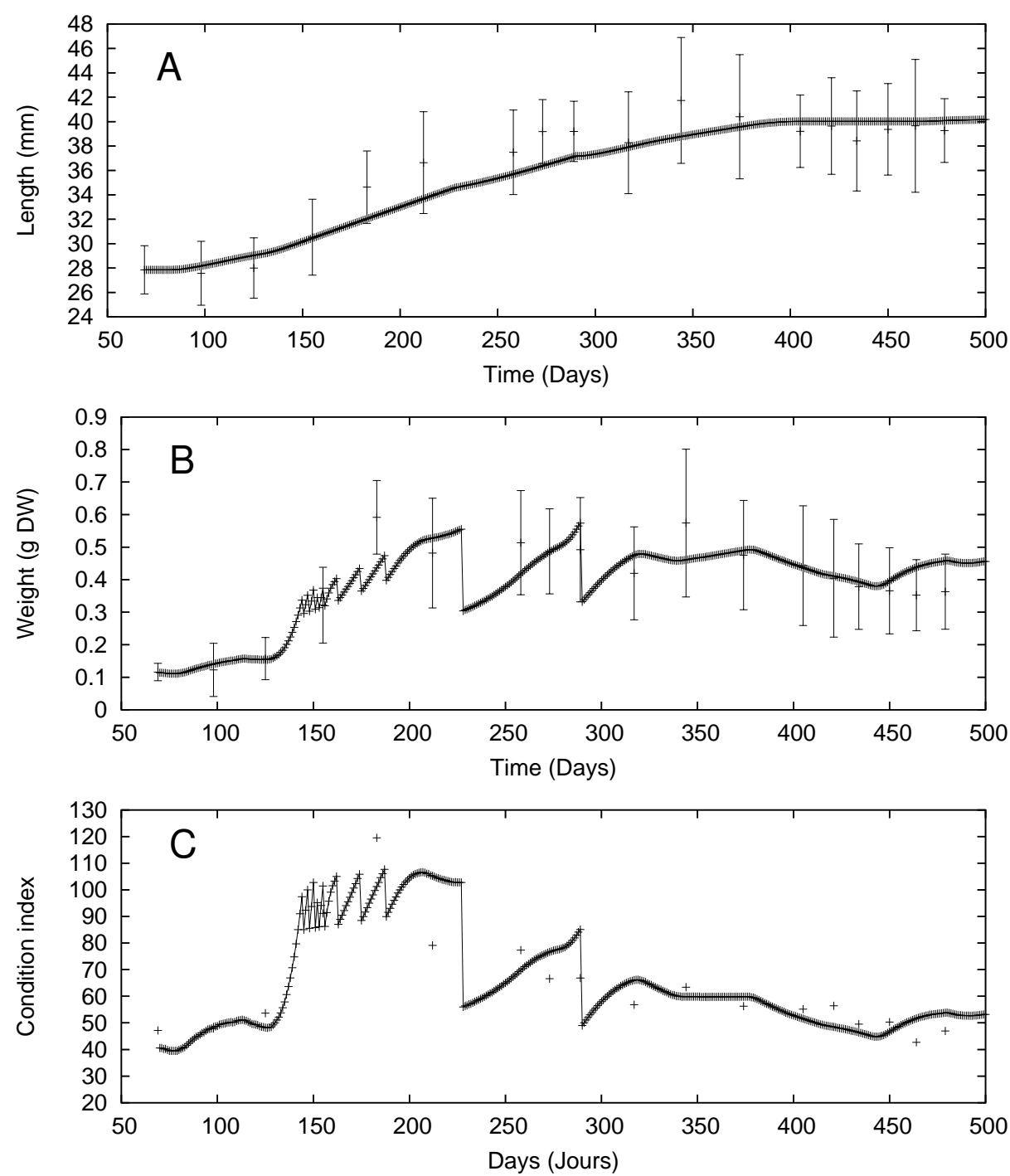

Fig. 6. Results of the validation of the model at Lilleau for length (A), weight (B) and condition index (C). Continuous lines show model output, crosses $(+)$ show observed data points and errorbars indicate standard deviation for field data (Goulletquer, 1989a). Standard deviations for condition index were not available. Time (days) is counted from the 1st of January 1985.

bivalves, length is calculated from weight through an allometric equation. In present study weight and length are two state variables independently calculated. Such a formulation for the Manila clam allowed uncoupling of length growth increments and weight growth increments. This is in agreement with observations of Lewis and Cerrato (1997) on Mya arenaria, which showed that shell growth could be uncoupled from somatic growth. Simulations were in a very good agreement with field data as the coefficient of correlation values were very high $\left(r^{2}=0.89\right.$ at Lilleau and $r^{2}=0.95$ at Nole). This formulation also allowed our model to simulate post-spawning shell growth stops, which were shown by Garcia (1993) in R. decussatus. 
Weight, condition index and reproductive patterns

For both Nole and Lilleau sites, the simulated reproductive pattern deviated somewhat from field observations. The aim of most studies on growth of $R$. philippinarum is to assess the best cultivation strategy for maximizing growth. Most often, authors monitor the evolution of biological variables (length, weight and condition index are among the most common) of a set of homogeneously sized individuals (i.e. a cohort - Maître-Allain, 1982; Bodoy et al., 1980; Goulletquer et al., 1987; Goulletquer, 1989a; Robert et al., 1993). On each sampling occasion, all individuals in the sample are sacrified to assess those variables and an average length, weight or condition index is calculated. Using such a method, one obtains the trajectory of the average weight, length and condition index of a cohort through time. It is often said to be the trajectory of an "average individual" (i.e. an individual that has average physiological features), although no real individual trajectories are involved in such a data set.

The occurrence of asynchronous events, like partial spawnings, may induce a difference between the trajectory of an "average individual" and the trajectory of the average of a cohort. In order to explain this difference, two theoretical cases are hypothesized both of which lead to the same average-cohort-weight time series (Fig. 7).

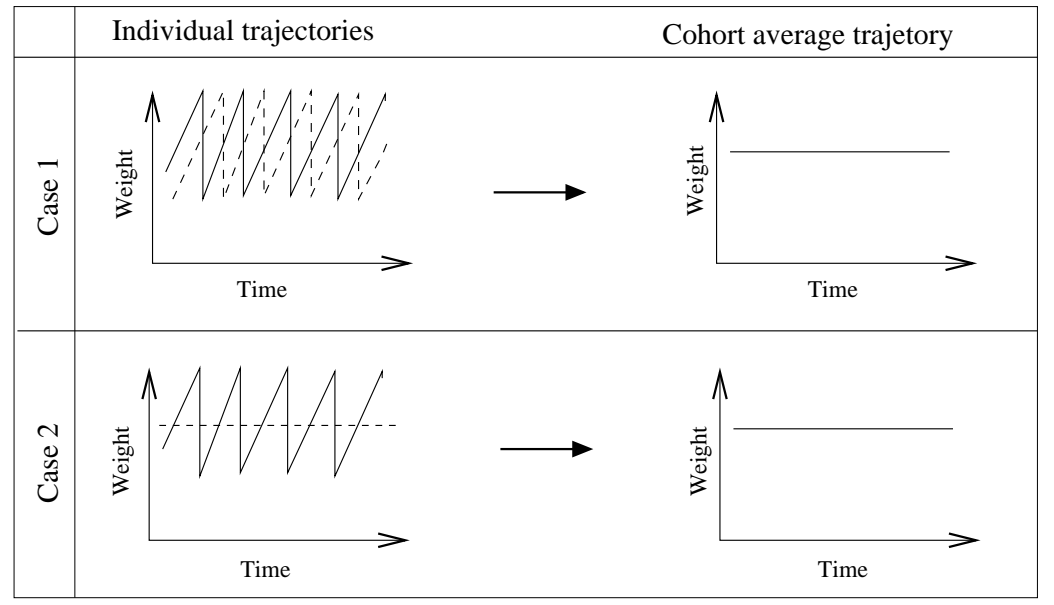

Fig. 7. Two hypothetical cases of the inter-individual variability of spawning strategy in a cohort. Case 1: the cohort is composed of individuals presenting similar spawning efforts, with each individual spawning four times, but not simultaneously. The individual trajectories graph shows the evolution of weights of two individuals (continuous and dotted lines). Case $2:$ the cohort is composed of individuals presenting different spawning strategies. One class of individuals spawns four times (continuous line in individual trajectories) and the other doesn't spawn at all (dotted lines in individual trajectories). In both cases, because of the asynchronous spawnings, the average weight of the cohort may remain constant.

- Case 1 is a situation where all individuals of the cohort have the same spawn- 
ing behaviour: each individual spawns with a high frequency, as shown by the individual weight trajectories. If these spawnings don't occur simultaneously in all the individuals of the cohort, the average weight of the cohort may remain constant.

- Case 2 is a situation where the cohort is composed of two kinds of individuals: some of them spawn with a high frequency and the other ones don't spawn at all. As in case 1, if spawnings, when they occur, are not synchronous, the average weight of the cohort may also remain constant.

In both cases, one may obtain the same evolution of average weight; however, the weight variance will be higher in case 1 . It is impossible, however, to make assumptions about the behavior of individuals and to distinguish between the two cases just by examining the mean and variance of the weight of the cohort. Processes of reproduction in bivalves are much more complex than these two examples; however, these two theoretical cases illustrate that if asynchronous events occur in a cohort, the average trajectory of the cohort doesn't allow any assumption about individual behavior.

Consequently, simulations of individual variables cannot easily be compared to observed data when asynchronous events occur within a cohort. Trying to fit a model simulating the evolution of mean weight of the cohort when asynchronous partial spawning events occur would not include these events thus resulting in a large underestimate of the reproductive output because it does not take into account the peak reproductive output of individuals clams. In such a case, a high value of the coefficient of correlation (i.e. tending toward 1) between simulated and field data may actually reveal a poor representation of individual behavior. This points out (1) the difficulty of comparing modeled to observed data during the reproductive season and (2) the difficulty of evaluating quantitatively the reproductive output of an "average individual".

For all these reasons, deviations of the model from observed weight and condition index values during the gamete-emission season appear relevant: they explain the lower values of the coefficients of determination obtained for weight and condition index in the validation simulations at Nole $\left(r^{2}=0.64\right.$ and 0.77 , respectively) and at Lilleau $\left(r^{2}=0.77\right.$ and 0.71 , respectively); they also explain the weak value of the slope of regression line between observed and modeled condition index at Nole. During the spawning season, goodness of fit of the simulated weight and condition index can't be validated: poor fit could be attributed to both (1) high variability among individual weights and condition indexes or (2) poor model representation of the individual energy balance. Thus the model should be validated outside of the reproductive season. When excluding the main spawning season (i.e. from mid May to mid September), simulations of both variables were very close to the observed data; coefficients of determination calculated for weight were higher $\left(r^{2}=0.86\right.$ at Nole and 0.84 at Lilleau) and the slopes of the regression lines between observed and simu- 
lated values were not significantly different from 1 ( $t$-test, $p$-value $>0.05)$ for all state variables. This indicates that our model properly estimates the Manila clam energy balance under forcing by temperature and trophic resource.

Several population dynamics models have been built for bivalves, which use bioenergetic equations to simulate bivalves standing stock transfers among size classes (Powell et al., 1992; Hofmann et al., 1992). They are not individually based. This strategy allows a direct comparison between the model outputs and the experimental data means. Nevertheless, the present study clearly shows that observation at the cohort (or the population) scale may hide some individual-scale processes. As individuals can be considered the basic entity of populations (Kooijman, 1995), the individual-scale processes influence populations processes. This problem of scale transfer was emphasized by Kooijman (1995). The Manila clam model has been developed in order to build a population dynamics, individual-based model following that developed by Hofmann et al. (2006) for Mercenaria mercenaria. This strategy permits accounting for the influence of individual-scale processes at the population level.

\section{Trophic resource}

The problem of estimating food resources available to suspension feeding bivalves is well known and recognized as a major problem in modelling bivalve energetics (see e.g. Bayne, 1998; Grant and Bacher, 1998). The Manila clam uses food resources available at the sediment-water interface, and may have a very complex diet : it is known for filtering prey items as diverse as bacteria, picocyanobacteria (Nakamura, 2001) and diatoms, as well as detritic particulate organic matter and small rotifers (Sorokin and Giovanardi, 1995) from the water column and the sediment surface. The Manila clam has also been described as ingesting toxic and non toxic dinoflagellates by $\mathrm{Li}$ and Wang (2001). Moreover, growth of microphytobenthos is very effective on the Marennes-Oléron mudflats (Guarini et al., 2000), and was shown to be an important food source for oysters Crassostrea gigas (Riera and Richard, 1996) once resuspended by tidal currents (Blanchard et al., 1998, 2001). In such mudflats, we can hypothesize that microphytobenthos is an important food source for near-bottom suspension-feeding bivalves such as $R$. philippinarum. Fegley et al. (1992) have shown that short-term variability in the quantity and nutritional quality of food items available to intertidal near-bottom suspension feeders like $R$. philippinarum may be of particular importance for assessing their growth and reproduction.

Insufficient information is available concerning these diverse potential food sources and the associated variability of feeding rate for them to be considered in our study. We used a classical and simple proxy $(C h l a)$, which represents 
a rough estimate of the food input $(C h l a \times C 2 F)$ for clams exhibiting such a complex diet. Following Grant and Bacher (1998) with Mytilus edulis, our simulations demonstrate that simple formulation of food and feeding may suffice in predicting Manila clam energetics. A careful study of the clam diet, using carbon and nitrogen isotope ratios (Kasai et al., 2004) and pigment analysis of bottom interface water POM, should improve our knowledge.

\section{Conclusion}

Despite the difficulty of comparing field-averaged data sets to model outputs, simulation of growth and reproduction for an "average" individual clam under natural food and temperature gave realistic results. The model can be used to predict length and weight growth as well as gamete production of Manila clams in temperate ecosystems. Further work will focus on modelling interactions between environment, host and pathogen using our results, which provide the environment-clam coupling.

\section{Acknowledgements}

This study was financed by a NSF-CNRS joint program. It was also supported by the Conseil Régional de Bretagne within the MODELMAB regional research program. The authors thank Me Folace and B. Lecaunar for their technical help. This is IUEM contribution No 1023.

\section{References}

Allam, B., Paillard, C., 1998. Defense factors in clam extrapallial fluids. Dis. Aquat. Org. 33, 123-128.

Allam, B., Paillard, C., Howard, A., Le Pennec, M., 2000. Isolation of the pathogen Vibrio tapetis and defense parameters in brown ring diseased Manila clams Ruditapes philippinarum cultivated in England. Dis. Aquat. Org. 41, 105-113.

Barillé, L., Héral, M., Barillé-Boyer, A.-L., 1997. Modélisation de l'écophysiologie de l'huitre Crassostrea gigas dans un environnement estuarien. Aquat. Living Resour. 10, 31-48.

Bayne, B. L., 1998. The physiology of suspension feeding by bivalve molluscs: an introduction to the Plymouth 'TROPHEE' workshop. J. Exp. Mar. Biol. Ecol. 219, 1-19. 
Blanchard, G. F., Guarini, J.-M., Bacher, C., Huet, V., 1998. Control of the short-term dynamics of intertidal microphytobenthos by the exondationsubmersion cycle. C. R. Acad. Sci. Paris, Sciences de la vie / Life Sciences 321 (6), 501-508.

Blanchard, G. F., Guarini, J. M., Orvain, F., Sauriau, P. G., 2001. Dynamic behaviour of benthic microalgal biomass in intertidal mudflats. J. Exp. Mar. Biol. Ecol. 264, 85-100.

Bodoy, A., Maitre-Allain, T., Riva, A., 1980. Croissance comparée de la palourde européenne (Ruditapes decussatus) et de la palourde japonaise (Ruditapes philippinarum) dans un écosystème artificiel meditérannéen. Vie Marine 2, 39-51.

Bower, S. M., 1992. Winter mortalities and histopathology in Manila clams (Tapes philippinarum) in British Columbia due to freezing temperature. J. Shellfish Res. 11 (2), 255-263.

Calvez, I., 2003. Approche de la variabilité spatiale d'une population de palourdes Ruditapes philippinarum (Adams et Reeve), aux stades larvaires et postlarvaires. Thèse de Doctorat, Université de Bretagne Occidentale, Brest.

Dame, R., 1996. Ecology of marine bivalves: an ecosystem approach. CRC Press, Boca Raton.

Fegley, S. R., MacDonald, B. A., Jacobsen, T. R., 1992. Short-term variation in the quantity and quality of seston available to benthic suspension feeders. Estuar. Coast. Shelf Sci. 34 (4), 393-412.

Flassch, J. P., Leborgne, Y., 1992. Introduction in Europe, from 1972 to 1980, of the Japanese Manila clam (Tapes philippinarum) and effects on aquaculture production and natural settlement. ICES J. Mar. Sci. 194, 92-96.

Fréchette, M., Alunno-Bruscia, M., Dumais, J.-F., Sirois, R., Daigle, G., 2005. Incompleteness and statistical uncertainty in competition stocking experiments. Aquacult. 246, 209-225.

Gangnery, A., Chabirand, J.-M., Lagarde, F., Le Gall, P., Oheix, J., Bacher, C., Buestel, D., 2003. Growth model of the Pacifc oyster, Crassostera gigas cultured in Thau Lagoon (Méditerranée, France). Aquacult. 215, 267-290.

Garcia, F., 1993. Interpretation of shell marks for the estimation of growth of the European carpet clam Ruditapes decussatus L. of the Bay of Fos (Mediterranean Sea). Oceanol. Acta 16, 199-203.

Goulletquer, P., 1989a. Etude des facteurs environnementaux intervenant sur la production de palourde japonnaise d'élevage Ruditapes philippinarum. Thèse de Doctorat, Université de Bretagne Occidentale, Brest.

Goulletquer, P., 1989b. Mortalité hivernale chez la palourde japonnaise $R u$ ditapes philippinarum sur le littoral atlantique : aspects biochimiques et écophysiologiques. Haliotis 17, 152-163.

Goulletquer, P., Heral, M., Deslous-Paoli, J.-M., Prou, J., Garnier, J., Razet, D., Boromthanarat, W., 1989. Ecophysiology and energy balance of the Japanese clam Ruditapes philippinarum. J. Exp. Mar. Biol. Ecol. 132, 85108.

Goulletquer, P., Lombas, I., Prou, J., 1987. Influence du temps d'immersion sur 
l'activité reproducrice et sur la croissance de la palourde japonaise Ruditapes philippinarum et l'huitre japonaise Crassostrea gigas. Haliotis 16, 453-462.

Goulletquer, P., Wolowicz, M., 1989. The shell of Cardium edule, Cardium glaucum and Ruditapes philippinarum : Organic content, composition and energy value, as determined by different methods. J. Mar. Biol. Assoc. UK $132,563-572$.

Grant, J., Bacher, C., 1998. Comparative models of mussel bioenergetics and the validation at field culture sites. J. Exp. Mar. Biol. Ecol. 219, 21-44.

Guarini, J. M., Blanchard, G. F., Gros, P., 2000. Quantification of the microphytobenthic primary production in European intertidal mudflats - a modelling approach. Cont. Shelf Res. 20 (12-13), 1771-1788.

Hawkins, A., Duarte, P., Fang, J., Pascoe, P., Zhang, J., Zhu, M., 2002. A functional model of responsive-feeding and growth in bivalve shellfish, configured and validated for the scallop Chlamys farreri during culture in China. J. Exp. Mar. Biol. Ecol. 281, 13-40.

Hofmann, E. E., Klinck, J. M., Kraeuter, J. N., Powell, E. N., Grizzle, R. E., Buckner, S. C., Bricelj, M. V., 2006. A population model of the hard clam, Mercenaria mercenaria: development of the age- and length-frequency structure of the population. Journal of Shellfish Research 25, 417-444.

Hofmann, E. E., Powell, E. N., Klinck, J. M., Wilson, E. A., 1992. Modeling oyster populations III. Critical feeding periods, growth and reproduction. Journal of Shellfish Research 11, 399-416.

Kasai, A., Horie, H., Sakamoto, W., 2004. Selection of food sources by $R u$ ditapes philippinarum and Mactra veneriformis (Bivalvia: Mollusca) determined from stable isotope analysis. Fish. Sci. 70 (1), 11-20.

Kooijman, S. A. L. M., 1995. The stoichiometry of animal energetics. Journal of Theoretical Biology 177 (2), 139-149.

Laruelle, F., 1999. Phénologie et déterminisme de la reproduction chez Ruditapes decussatus (L.) and Ruditapes philippinarum (Adams and Reeve) en Bretagne. Thèse de Doctorat, Université de Bretagne Occidentale, Brest.

Laruelle, F., Guillou, J., Paulet, Y., 1994. Reproductive pattern of the clams, Ruditapes decussatus and Ruditapes philippinarum, on intertidal flats in Brittany. J. Mar. Biol. Assoc. UK 172, 69-96.

Lawrence, D., Scott, G., 1982. The determination and use of condition index of oysters. Estuaries 5, 23-27.

Lewis, D. E., Cerrato, R. M., 1997. Growth uncoupling and the relationship between shell growth and metabolism in the soft shell clam Mya arenaria. Mar. Ecol. Prog. Ser. 158, 177-189.

Li, S.-C., Wang, W.-X., 2001. Radiotracer studies on the feeding of two marine bivalves on the toxic and nontoxic dinoflagellate Alexandrium tamarense. J. Exp. Mar. Biol. Ecol. 263 (1), 65-75.

Lucas, A., 1993. Bioénergétique des animaux aquatiques. Masson, Paris.

Lucas, A., Beninger, P., 1985. The use of physiological indices in marine bivalve aquaculture. Aquacult. 44, 187-200.

Mann, R., 1979. The effects of temperature on growth, physiology and game- 
togenesis in the Manila clam Tapes philippinarum (Adams \& Reeve, 1850). J. Exp. Mar. Biol. Ecol. 38, 121-133.

Maître-Allain, T., 1982. Influence du milieu sur la croissance de deux palourdes, Ruditapes decussatus et Ruditapes philippinarum, dans l'étang de Thau (Hérault). Vie Marine 4, 11-20.

Meneghetti, F., Moschino, V., Da Ros, L., 2004. Gametogenic cycle and variations in oocyte size of Tapes philippinarum from the lagoon of Venice. Aquacult. 240, 473-488.

Mortensen, S., Strand, O., 2000. Release and recapture of Manila clams (Ruditapes pilippinarum) introduced to Norway. Sarsia 85, 87-91.

Nakamura, Y., 2001. Filtration rates of the Manila clam, Ruditapes philippinarum: dependence on prey items including bacteria and picyanobacteria. J. Exp. Mar. Biol. Ecol. 206, 181-192.

Ngo, T. T. T., Choi, K.-S., 2004. Seasonal change of Perkinsus and Cercaria infections in the manila clam Ruditapes philippinarum from Jeju, Korea. Aquacult. 239, 57-68.

Paillard, C., Allam, B., Oubella, R., 2004. Effects of temperature on defense parameters in Manila clam Ruditapes philippinarum challenged with Vibrio tapetis. Dis. Aquat. Org. 59, 249-262.

Paillard, C., Maes, P., 1990. Etiologie de la maladie de l'anneau brun chez Tapes philippinarum : pathogénicité d'un Vibrio sp. C. R. Acad. Sci. Paris, Sciences de la vie / Life Sciences 310, 15-20.

Paillard, C., Maes, P., 1994. Brown ring disease in the Manila clam Ruditapes philippinarum: establishment of a classification system. Dis. Aquat. Org. 19, 137-146.

Paillard, C., Maes, P., Oubella, R., 1994. Brown ring disease in clams. Ann. Rev. Fish Disease 4, 219-240.

Paillard, C., Percelay, L., Le Pennec, M., Le Picard, D., 1989. Origine pathogène de la maladie de l'anneau brun chez Tapes philippinarum (Mollusque, Bivalve). C. R. Acad. Sci. Paris, Sciences de la vie / Life Sciences 309, 335-341.

Park, K.-I., Choi, K.-S., 2004. Application of enzyme-linked immunosorbent assay for studying of reproduction in the Manila clam Ruditapes philippinarum (Mollusca: Bivalvia) I. Quantifying eggs. Aquacult. 241, 667-687.

Pouvreau, S., Bacher, C., Héral, M., 2000. Ecophysiological model of growth and reproduction of the black pearl oyster, Pinctada margaritifera: potential applications for pearl farming in French Polynesia. Aquacult. 186, 117-144.

Powell, E. N., Hofmann, E. E., Klinck, J. M., Ray, S. M., 1992. Modelling oyster populations I. A commentary on filtration rate. Is faster always better ? Journal of Shellfish Research 2, 387-398.

Powell, E. N., Stanton, R. J., 1985. Estimation of biomass and energy flow of molluscs in palaeo-communities. Palaeontology 28, 1-34.

Pérez Camacho, A., Delgado, M., Fernandez-Reiriz, M., Labarta, U., 2003. Energy balance, gonad developement and biochemical composition in the clam Ruditapes decussatus. Mar. Ecol. Prog. Ser. 258, 133-145. 
Riera, P., Richard, P., 1996. Isotopic determination of food sources of Crassostrea gigas along a trophic gradient in the estuarine bay of MarennesOléron. Estuar. Coast. Shelf. Sci. 42, 347-360.

Robert, R., Trut, G., Laborde, J. L., 1993. Growth, reproduction and gross biochemical composition of the Manila clam Ruditapes philippinarum in the Bay of Arcachon, France. Mar. Biol. 116, 291-299.

Shafee, M. S., Lucas, A., 1982. Variations saisonnières du bilan énergétique chez les individus d'une population de Chlamys varia (L.): Bivalvia, pectinidae. Oceanol. Acta 5, 331-338.

Sorokin, Y., Giovanardi, O., 1995. Trophic characteristics of the Manila clam (Tapes philippinarum Adams and Reeve). ICES J. Mar. Sci. 52 (5), 853-862.

Thompson, R. G., 1984. Production and reproductive effort in the blue mussel Mytilus edulis, the sea urchin Strongylocentrotus droebachiensis and the snow crab Chionocetes opilio from populations in Nova Scotia and Newfoundland. J. Fish. Res. Board Canada 36, 955-964.

Toba, M., Natsume, Y., Yamakawa, H., 1993. Reproductive cycle of Manila clams collected from Funabashi waters, Tokyo bay. Nippon Suisan Gakkaishi 59 (1), 15-22. 